\title{
EMPLOYERS BAITUL ARQAM PROGRAM EVALUATION IN MUHAMMADIYAH UNIVERSITY Of PALANGKARAYA
}

\author{
Nurul Hikmah Kartini \\ Elementary School Teacher Education, Faculty of Teachers Training and Education (FKIP), Muhammadiyah \\ University of Palangkaraya \\ Palangkaraya, Indonesia \\ nurul.kartini@umpalangkaraya.ac.id
}

\begin{abstract}
Muhammadiyah University of Palangkaraya is conducting certain members recruitment program for its employers on every Ramadhan, which is called Baitul Arqam. Issue found in this institution is that not all employers comprehend what is Al Islam and the Muhammadiyah-ism to be implemented in everyday life and worship. This Baitul Arqam program is one of implemented solution as the answer. As the program has been conducted for more than 3 (three) years, evaluation is necessary. This evaluation aims to identify Employers Baitul Arqam Program in Muhammadiyah University of Palangkaraya effectivity. This study applies CIPP evaluation model. CIPP evaluation model created by Stufflebeam focuses on four aspects, ie.: context, input, process, and product. Data sampling is performed through interviews, observations, and documentation. Study subjects as human information resources are University Chancellor, $1^{\text {st }}$ Vice Chancellor, $2^{\text {nd }}$ Vice Chancellor, Islamic Muhammadiyah-ism Development Institution (LPPKK) Director, Trainers, and Trainees/ employers in Muhammadiyah University of Palangkaraya, by taking samples of 80 individuals. Evaluation categorizations are divided into five ratings: Very Good, Good, Fair, Bad, and Very Bad. Evaluation result shows that: 1) Program requirements as well as its purposes and targets analysis regarding context component is categorized as very good.; 2) Planning strategy which includes material, human resources, means and infrastructure, fund, and learning method regarding inputs component in the BBTHA program in Muhammadiyah University of Palangkaraya is categorized as good; 3) In term of process component executed on the Employers Baitul Arqam program is categorized as good; 4) In term of product as the result of Employers Baitul Arqam program is categorized as good. The conclusion is, this Program can be proceed forward followed by some improvements.
\end{abstract}

Keywords: program evaluation, Employer Baitul Arqam

The expectation toward education written on the legal rules focusing on all educational aspects, these include educational resources as well as students, to proceed learning process. Regarding first purpose which is to build a religious and faithful human being to the God Almighty, Muhammadiyah University of Palangkaraya by its slogan "The Green Islamic Campus" attempts to straighten Islamic indicator to reinforce education expectation as well as education objectives according to the constitution.

As the incarnation on Islamic indicator, there are many things that may have role as our lifetime program. One of Islamic indicator incarnation to develop lecturers as well as educational human resources is by mean of member recruitment process which is called Baitul Arqam. The importance of this member recruitment process is starting from deeper insight on Muhammadiyah. Baitul Arqam is formed by two words: bait (home) and arqam (inspired by Arqam bin Abil Arqam, a youth group who were pioneers to convert to Islam during Rasullullah era). Baitul Arqam is one of Muhammadiyah recruitment system focusing in ideology development (Al Islam and Muhammadiyah-ism) and leadership within an union. It is aim to create attitude, integrity, perception and way of thinking uniformity and homogeneity within Muhammadiyah Alliance and Charity Effort. 
This program as a manifestation of consentient in mindfulness and action for Muhammadiyah sustainability and progress in the near future. Since this Employers Baitul Arqam is one of the program, so an evaluation is required to see the program successful level. Purwanto said, there are three reasons why program evaluation is important, ie. 1) As a review of accomplishment existence and funding, 2) As a basic to decide whether the program should continue or suspended, 3) As a tool to collect information on how to develop the program in the future. It is expected that evaluation result a decision will be determined whether the program should proceed or being canceled. Based on this background, some concerns can be defined as follow:

1. How are requirements, purposes and targets analysis on the context level of Employers Baitul Arqam in Muhammadiyah University of Palangkaraya?

2. What is the planning strategy which consists of materials, human resources, means and infrastructure, funds, and learning method on the input level of Employers Baitul Arqam program in Muhammadiyah University of Palangkaraya?

3. What are activities schedule, learning activities, as well as monitoring and evaluation on the process level during the proceeding of Employers Baitul Arqam program in Muhammadiyah University of Palangkaraya?

4. How is participants competency on the product level of Employers Baitul Arqam program in Muhammadiyah University of Palangkaraya?

Regarding these concerns, this study aims to find out the evaluation of Employers Baitul Arqam in Muhammadiyah University of Palangkaraya. Significantly, this study aims to: 1 . Discover the requirements, purposes and targets analysis on the context level in Employers Baitul Arqam in Muhammadiyah University of Palangkaraya. 2. Discover the planning strategy which consists of materials, human resources, means and infrastructure, funds, and learning method on the input level in Employers Baitul Arqam program in Muhammadiyah University of Palangkaraya. 3. Discover the activities schedule, learning activities, as well as monitoring and evaluation on the process level during the proceeding of Employers Baitul Arqam program in Muhammadiyah University of Palangkaraya.4. Discover the participants competency on the product level of Employers Baitul Arqam program in Muhammadiyah University of Palangkaraya. Program evaluation models have been recognized and improved by the experts. Basically, each model has its pros and cons.

Regarding a program evaluation, there are some evaluation models defined by the expert. Purwanto differentiates eight evaluation models, i.e: 1) Scriven's formative-sumative model, 2) CIPP model, 3) CSE-UCLA model, 4) Stake's countenance model, 5) Tyler's goal attainment model, 6) Provus' discrepancy model, 7) Scriven goal free model, 8) Kirkpatrick model.

Based on the above models, CIPP evaluation model is explained as the following. CIPP evaluation model is developed by Stufflebeam. Basic concept of the CIPP evaluation model is to proceed evaluation of the: context, input, process, and product. Context evaluation assists in developing a program goal. Input 
evaluation assists in program preparation. Process evaluation assists in represent program proceeding, and product evaluation is an evaluation of the out put as a study material regarding on board program decision making. This evaluation model is appropriate to evaluate a program execution effectivity (Daniel L. Stufflebeam, 2007: 345).

\section{METHOD}

This CIPP evaluation study was conducted in Muhammadiyah University of Palangkaraya, located in Jalan RTA Milono KM 1,5 Palangkaraya, Central Kalimantan. The study duration was four months, from January to April 2017. CIPP evaluation model study design is represented on table 1:

\begin{tabular}{|c|c|c|}
\hline \multicolumn{3}{|c|}{$\begin{array}{c}\text { Employers Baitul Arqam Program in } \\
\text { Muhammadiyah University of Palangkaraya }\end{array}$} \\
\hline Components & Indicators & Result \\
\hline - Context & $\begin{array}{l}\text { - Program compatibility with institution } \\
\text { and society necessity analysis } \\
\text { - Available legal basic conformity } \\
\text { - Program goal and target conformity } \\
\text { with vision, mision, and aims of the } \\
\text { institution. }\end{array}$ & $\begin{array}{l}\text { Quality improvement of the } \\
\text { Employers Baitul Arqam } \\
\text { Program in Muhammadiyah } \\
\text { University of Palangkaraya }\end{array}$ \\
\hline $\begin{array}{l}\text { - Input } \\
\text { - Process }\end{array}$ & $\begin{array}{l}\text { - Material content clarity } \\
\text { - Trainers and trainees meet the } \\
\text { requirements } \\
\text { - Means and infrastructure availability as } \\
\text { accordance with standards } \\
\text { - Funds support availability } \\
\text { - Varied and innovative method } \\
\text { availability }\end{array}$ & \\
\hline - Product & $\begin{array}{l}\text { - BBTHA schedule availability } \\
\text { - Activities implementation } \\
\text { - Limited funds issue } \\
\text { Baitul Arqam participans have } \\
\text { competency regarding Islamism and } \\
\text { Muhammadiyah-ism understanding }\end{array}$ & \\
\hline
\end{tabular}

Applied research method is qualitative study, which is a study of collected data and describe in words and images. Words are arranged in sentence, such as, sentences of an interview between researcher and informant. Qualitative study is based on constructivism philosophy which assumes that the study is multidimentional, interactive, and a social experiment exchange interpreted by individuals.

Study subjects consist of every elements involved in Employers Baitul Arqam program in Muhammadiyah University of Palangkaraya, ie: 1) Chancellor; 
2) LPPKK Director; 3) Program trainers; 4) Employers/ program trainees.

In this case, informants from the Chancellor side are Chancellor, $1^{\text {st }}$ Vice Chancellor, and $2^{\text {nd }}$ Vice Chancellor of the Muhammadiyah University of Palangkaraya. Vice Chancellor as the employee of the LPPKK Institution Director is expected to notice evaluated program policy direction. Program trainers are person who interact directly with trainees during the program, in this case they consisted of Muhammadiyah Regional Leaders in Central Kalimantan. Program trainees are Muhammadiyah University of Palangkaraya employers of all workforce unit representations. Sample is taken from at least 80 respondents. Methods applied in this study are interviews, observations, and document studies.

\section{RESULT}

Concluded result of the "Employers Baitul Arqam Program in Muhammadiyah University of Palangkaraya" presented evaluation findings of four model evaluations, ie: context, input, process, and product. This result study is obtained from data collecting technique of interviews, documentations, and observations. After data sampling was done, researcher verified data validity of each evaluation models. The result are shown as follows.

Table 3.1 Context Evaluation Result

\begin{tabular}{|c|c|c|}
\hline Evaluation Criteria & Evaluation Findings & Conclusions \\
\hline $\begin{array}{l}\text { There is necessities } \\
\text { analysis of Employers } \\
\text { Baitul Arqam Program } \\
\text { consistent with institution } \\
\text { and society necessities } \\
\text { analysis }\end{array}$ & $\begin{array}{l}\text { There is necessities analysis } \\
\text { before Employers Baitul Arqam } \\
\text { program created in accordance } \\
\text { with instution and society } \\
\text { necessities }\end{array}$ & $\begin{array}{l}100 \% \\
\text { accomplished with } \\
\text { "very good" } \\
\text { category }\end{array}$ \\
\hline $\begin{array}{l}\text { The conformity of } \\
\text { Employers Baitul Arqam } \\
\text { purpose and target with } \\
\text { Muhammadiyah } \\
\text { University of Palangkaraya } \\
\text { and LPPKK workforce } \\
\text { unit visions, missions, and } \\
\text { purposes }\end{array}$ & $\begin{array}{l}\text { 1. There is conformity between } \\
\text { Employers Baitul Arqam program } \\
\text { purpose and target with the } \\
\text { University Visions } \\
\text { 2. There is conformity between } \\
\text { Employers Baitul Arqam program } \\
\text { purpose and target with the } \\
\text { University Missions } \\
\text { 3. There is conformity between } \\
\text { Employers Baitul Arqam program } \\
\text { purpose and target with the } \\
\text { University Purposes }\end{array}$ & $\begin{array}{l}100 \% \\
\text { accomplished with } \\
\text { "very good" } \\
\text { category }\end{array}$ \\
\hline
\end{tabular}




\begin{tabular}{|l|l|l|}
\hline Evaluation Criteria & Evaluation Findings & Conclusions \\
\hline & $\begin{array}{l}\text { 4. There is conformity between } \\
\text { between Employers Baitul Arqam } \\
\text { program purpose and target with } \\
\text { the LPPKK Visions }\end{array}$ & \\
$\begin{array}{l}\text { 5. There is conformity between } \\
\text { Employers Baitul Arqam program } \\
\text { purpose and target with the } \\
\text { LPPKK Missions }\end{array}$ & $\begin{array}{l}\text { 6. There is conformity of program } \\
\text { purpose and target with LPPKK } \\
\text { purposes }\end{array}$ & \\
\hline
\end{tabular}

Table 3.2 Input Evaluation Result

\begin{tabular}{|l|l|l|}
\hline Evaluation Criteria & Evaluation Findings & Conclusions \\
\hline $\begin{array}{l}\text { 1. Baitul Arqam I group } \\
\text { material content clarity } \\
\text { 2. Baitul Arqam II group } \\
\text { material content clarity }\end{array}$ & $\begin{array}{l}\text { Baitul Arqam I and II program } \\
\text { materials are convenient }\end{array}$ & $\begin{array}{l}100 \% \\
\text { accomplished with } \\
\text { "very good" } \\
\text { category }\end{array}$ \\
\hline $\begin{array}{l}\text { 1. Employers Baitul Arqam } \\
\text { trainers have specified } \\
\text { requirements } \\
\text { qualifications }\end{array}$ & $\begin{array}{l}\text { 1. Employers Baitul Arqam } \\
\text { human resources already meet the } \\
\text { requirements as set by proceeding } \\
\text { and technical guidance book } \\
\text { consisted of Muhammadiyah } \\
\text { Central Directors, } \\
\text { Muhammadiyah Regional } \\
\text { Directors and Aisyiyah Regional } \\
\text { Directors } \\
\text { 2. Trainees have been qualified } \\
\text { appropriately, in basic and } \\
\text { advance level } \\
\text { achievement with } \\
\text { "good" category }\end{array}$ \\
$\begin{array}{l}\text { 2. Employers Baitul } \\
\text { Arqam trainees have } \\
\text { specified requirements } \\
\text { qualifications } \\
\text { 3. There are workforce } \\
\text { units who manage the } \\
\text { program }\end{array}$ & $\begin{array}{l}\text { who managed the program, ie. } \\
\text { LPPKK }\end{array}$ & \\
\hline
\end{tabular}




\begin{tabular}{|c|c|c|}
\hline $\begin{array}{l}\text { The availability of means } \\
\text { and infrastructure in } \\
\text { accordance with } \\
\text { government standards }\end{array}$ & $\begin{array}{l}\text { 1. The availability of means and } \\
\text { infrastructure has meet the } \\
\text { standards and very helpful for } \\
\text { Employers Baitul Arqam program } \\
\text { 2. Worship practice media still } \\
\text { limited }\end{array}$ & $\begin{array}{l}\text { Evaluation criteria } \\
\text { fulfilled, } 61-80 \% \\
\text { achievement with } \\
\text { "good" category }\end{array}$ \\
\hline $\begin{array}{l}\text { 1. The availability of } \\
\text { sufficient funding } \\
\text { 2. There is significant } \\
\text { increasing in University } \\
\text { Income and Expense Plan } \\
\text { (APBU) }\end{array}$ & $\begin{array}{l}\text { 1. University funding is already } \\
\text { fulfilled the Employers Baitul } \\
\text { Arqam program needs } \\
\text { 2. There is change in numbers } \\
\text { then stable }\end{array}$ & $\begin{array}{l}100 \% \\
\text { accomplished with } \\
\text { "very good" } \\
\text { category }\end{array}$ \\
\hline $\begin{array}{l}\text { The availability of varied } \\
\text { learning methods }\end{array}$ & $\begin{array}{l}\text { Learning methods applied in } \\
\text { Employers Baitul Arqam program } \\
\text { given in theories, practices, using } \\
\text { significant medium such as videos }\end{array}$ & $\begin{array}{l}\text { Evaluation criteria } \\
\text { fulfilled, } 61-80 \% \\
\text { achievement with } \\
\text { "good" category }\end{array}$ \\
\hline
\end{tabular}

Table 3.3 Process Evaluation Result

\begin{tabular}{|c|c|c|}
\hline Evaluation Criteria & Evaluation Findings & Conclusions \\
\hline $\begin{array}{l}\text { 1. Trainees discipline in } \\
\text { following the set schedule } \\
\text { 2. As minimum as } 80 \% \text { of } \\
\text { schedule }\end{array}$ & $\begin{array}{l}\text { 1. Half of trainees indisposed the } \\
\text { set schedule, as it was on } \\
\text { Monday-Friday working days } \\
\text { 2. Generally, meeting frequencies } \\
\text { are accomplished }\end{array}$ & $\begin{array}{l}\text { Evaluation criteria } \\
\text { fulfilled, } 61-80 \% \\
\text { achievement with } \\
\text { "good" category }\end{array}$ \\
\hline $\begin{array}{l}\text { 1. The compatibility } \\
\text { between theory and } \\
\text { practice } \\
\text { 2. Post-test existed }\end{array}$ & $\begin{array}{l}\text { 1. } 90 \% \text { respondents answered that } \\
\text { there is no difficulty in following } \\
\text { Baitul Arqam materials } \\
2.90 \% \text { respondents answered } \\
\text { deceased burial is the most } \\
\text { interesting } \\
\text { 3. } 100 \% \text { respondents answered } \\
\text { that they followed pro-test in the } \\
\text { end of the meeting, even some of } \\
\text { them have forgotten what was the } \\
\text { pro-test content } \\
\text { 4. } 90 \% \text { respondents indisposed if } \\
\text { Baitul Arqam is conducted at } \\
\text { night outside the campus area }\end{array}$ & $\begin{array}{l}\text { Evaluation criteria } \\
\text { fulfilled, } 61-80 \% \\
\text { achievement with } \\
\text { "good" category }\end{array}$ \\
\hline
\end{tabular}




\begin{tabular}{|l|l|l|}
$\begin{array}{l}\text { There is limited } \\
\text { monitoring and evaluation } \\
\text { on BBTHA program as } \\
\text { long as 1 semester }\end{array}$ & $\begin{array}{l}\text { 1. Monitoring is performed by } \\
\text { LPPKK }\end{array}$ & $\begin{array}{l}\text { Evaluation criteria } \\
\text { fulfilled, 61-80\% } \\
\text { performed in LPPKK and } \\
\text { Chancellor meeting anually before } \\
\text { Ramadhan activities }\end{array}$ \\
"good" category \\
\end{tabular}

Table 3.4 Product Evaluation Result

\begin{tabular}{|l|l|l|}
\hline Evaluation Criteria & Evaluation Findings & Conclusions \\
\hline $\begin{array}{l}\text { Employers Baitul Arqam } \\
\text { participants have both } \\
\text { competencies in theory and } \\
\text { practice regarding Al-islam } \\
\text { and Muhammadiyah-ism }\end{array}$ & $\begin{array}{l}\text { Based on passing decree, it is } \\
\text { known that most of Baitul Arqam } \\
\text { participants are passed }\end{array}$ & $\begin{array}{l}\text { Evaluation criteria } \\
\text { fulfilled, 61-80\% } \\
\text { achievement with } \\
\text { "good" category }\end{array}$ \\
& \\
\hline
\end{tabular}

Commentary is an activity to compare between the findings and specified evaluation criteria. This study consists of 4 (four) major evaluation sections, ie: context, inputs, process, and product. The commentary will be based on these four sections. Each components findings commentaries based on questions definition will be explained as follow.

\section{Context Evaluation}

Regarding context evaluation, there are two aspects to evaluate: 1) Necessities analysis and; 2) Program objectives and targets. a. First compponent ie. necessities analysis, in accordance with evaluation result is in very good category. b. Second component ie. Program purposes and targets, based on evaluation result is in very good category. Regarding of its relevance with university visions, missions, and strategic plans. Muhammadiyah University of Palangkaraya is holdings its vision ie.: highly sophisticated in science and technology based on faith and religious. Regarding of Islamism, LPPKK workforce unit is created as an institution to manifest the university vision. This is can be seen from the conformity between university vision and LPPKK vision ie: to develop an Islamic college and academic society.

The relevance between university and institution vision and mission is reinforced within Muhammadiyah University of Palangkaraya Strategic Plan 2012-2016. Since the beginning, Muhammadiyah University of Palangkaraya has consolidated its determination and role as higher educational institution as well as the frontline of Muhammadiyah movement endeavor. This determination will always be the color of Muhammadiyah University of Palangkaraya development plan definition. Regarding to manifest this role, Muhammadiyah University of Palangkaraya is 
projected to be able to face local, regional, as well as global challenges. Key of success on a competition is human resources quality, not natural resources abundance potency. As to enter the competition era, anticipation steps is a must. One of the anticipation step, significantly in Higher Education is the availability of strategic planning to answer challenges and society life issues, at least for the next ten

years.

LPPKK as a workforce unit to build University Strategy Plan in Islamism Muhammadiyah-ism field holds a mandate to perform working plan which is one of its programs is to build union recruitees. This is also in accordance with second section of university mission ie: to develop human resources based on Islamic values and to project change direction to build Indonesians as premier people. LPPKK not only cultivate and develop lecturers, employers Islamism Muhammadiyah-ism, but students as well. In order to increase employers quality in Al Islam and Muhammadiyah-ism, a recruitment program called Baitul Arqam is created.

Employers Baitul Arqam execution only perform once a year during Ramadhan. The program started since 2012 until present. This program is devided into two basic and advance groups. Islamic values aspects basically can be defined into three categories, aqidah values, worship values, and moral values. These values are considered to succeed in bring human into happiness, prosperity, and security, on Earth and afterlife as well (Muhtadi, 2006:25).

Data finding result will be validate further through triangulation data technique by digging information from other related party. In this case, information is received from Muhammadiyah University of Palangkaraya Chancellor as said on an interview

below:

Regarding vision, all road to success is passing through a process. There is short-term target, mid-term target, and long-term target. The same goes with any relation in mission execution. The nurture of obstacles or problems to face require central leadership role to solve the same mindset issue for the university progress. This is what all academic society, from the top to bottom echelons, must have. The uniformity in visions and missions will be accomplished if followed by continuous socialisation. Just like the wise man says, "keep going to find a way." As presented by philosophy expert in leadership management, the ideal ratio is $20 / 80.80 \%$ of the ability to become a leader and $20 \%$ of the ability to motivate. An important thing such as Employers Baitul Arqam program must be proceed continuously by the help of communication media, clear SOP, as well as consistency in performing Employers Baitul Arqam program.

The clarity of documents availability supported by interviews with the existed evaluation result/ findings, so this aspect can be categorized as Very Good.

\section{Input Evaluation}

Input evaluation is consisting of five components, which are: materials, human resources, means and infrastructure, funds, and method. Each of these will be explained below: 


\section{a. Materials}

Based on findings result, based on existed hand-book, the materials given are clear enough but have not well documented neatly in one standard book. Based on interviews, $>75 \%$ of participants are interested in funeral proceeding, starting from wash, shroud, to pray for the deceased. As of difficult materials to comprehend, only a few participants answered hadits material, also different rite of worship since not all of the employers are coming from Muhammadiyah circle. There are difficulties in changing wudhu rite and certain shala readings. Other than theory, participants ask for more worship practice. But this has been an issue since there is lack of time allocation for direct practice. So it is recommended to allocate additional time slot for deceased burial practice.

\section{b. Human Resources}

Human Resources components are divided into two aspects, ie.: Employers Baitul Arqam trainers and trainees. Based on the findings, researcher found that Employers Baitul Arqam program trainers are coming from Muhammadiyah Central Director and Regional Director, as well as Aisyiyah Regional Director of Central Kalimantan. Evaluation result concludes that for 4 years of Employers Baitul Arqam enforcement, trainers didn't rotate much each year based on their competencies and qualifications. Only $10 \%$ of the trainers candidate are just nominated right in the current year.

Next thing to discuss is related to Employers Baitul Arqam trainees. All employers of the Muhammadiyah University of Palangkaraya is obligated to join the program, and so the program consists of basic group and advanced groups. Basic group is a group for employers who were joining in the first year. While advanced group is a group of employers who passed the basic group a year earlier. Baitul Arqam passing certificate even becomes one of requirements for lecturers or educational employer to promote their careeers.

\section{c. Means and Infrastructure}

Basically, means and infrastructure owned by Muhammadiyah University of Palangkaraya is very appropriate, both of means and infrastructure. Based on Educational Minister Instruction Number 49 on Higher Education National Standards of education national means in means and infrastructure, such as: places, class rooms, library, laboratory/studio/workshop, production unit, exercise room, art room, students activities unit rooms, higher education director office, lecturers office, administration office, and public facility. From the set standards, infrastructures to support Employers Baitul Arqam program in Muhammadiyah University of Palangkaraya are: 1) Mosque; 2) Auditorium; 3) Class rooms; and 4) Library.

While on the clause 35 on learning tools which are at least consist of: furniture, educational equipment, educational media, books/e-books/repositories, information and communication technology means, experimental instrument, sports means, art means, public facility, disposal materials, and maintenance, dafety, and security infrastructure. Tools to support the program are: 1) furniture; 2) educational equipment; 3) educational media; and 4) books. 
Based on evaluation result, means and infrastructure are very appropriate to promote Employers Baitul Arqam program enforcement. The massive infrastructure development in the Muhammadiyah University of Palangkaraya is very reliable to support coaching process.

Regarding tools availability, LCD screen in the auditorium is very helpful on the learning process. The trainers are occasionally use learning media by playing related videos on worship practice like deceased burial.

But there is a weakness in this component, since learning media for practicing deceased shroud like mannequin is not available yet. All this time, special trainer on how to shroud a deceased ie. The ladies of Asyiyah Regional Director brought the media by themselves. This will be a recommendation to the workforce unit related to proceed learning media availability on fiqih term.

\section{d. Fund}

Fund support from the University for the Employers Baitul Arqam program is stated clearly and in details each year on University Income and Expense Budget Planning (APBU). Reviewing budget amount in the for years of Employers Baitul Arqam program enforcement, it is known that there is change in numbers. In 2013, available budget was Rp 15 million. In 2014 to present it was increasing to be Rp 30 millions. This is because the evaluation result of the earlier year based on accomplished budget and the planning readiness created by Institution director who manage the program. This shows that consecutive program readiness and implementation is succeeded, so that there's no obstacle in funding support.

\section{e. Methods}

Certain methods are implemented through speeches, discussions, Q\&As, and practice enforcement. Based on evaluation result, there is less time slot for worship practice. Researcher recommends to expand the session for worship practice on certain days.

\section{Process Evaluation}

Process evaluation review consists of three components ie: schedule, activities and monitoring, as well as evaluation. The components are discucced below respectively:

\section{a. Schedule}

Baitul Arqam program is enforced once a year in Ramadhan. On the early enforcements on 2012 and 2013, Baitul Arqam was held since after subuh until tarawih. But the enforcement was ineffective in practice since most of participants stay far away from the campus. Based on interview result, most of participants indisposed if Baitul Arqam was held in the evening, even only $10 \%$ agreed if the program was held outside the campus. Since 2013 to present the program is held in accordance with business hours in Muhammadiyah University of Palangkaraya.

In 2014, the institution decided to set 2 days for Baitul Arqam enforcement and invited trainers from Central Muhammadiyah Director, so all workforce services were off duty since most of employers were on Advanced level of Baitul Arqam. It has been proven that after this policy participants attendance and interest 
on materials became better. In 2015 to 2017, the off duty services policy is no longer exist, thus several participants were absent in one or two session of the program. Since most of participants if the basic and advanced group of the consecutive year are also lecturers, they found it was difficult to allocate their times if there's any thesis or practice examination. Some of Baitul Arqam participants were passed in condition since they have lack of time to follow the schedule. Based on this finding and discussion, it is recommended that Baitul Arqam participants are considered structural responsibility and students service free. This result is supported by interviews of $>90 \%$ participants intent to focus on the program and expect that they are not burdened by structural responsibility, and this can be stated by an official specified memo.

\section{b. Learning Activities}

Basically, learning activities which are about to be evaluated is from Baitul Arqam participants' side. Based on evaluation result, the enforcement of the program is in accordance with the the required criteria.

Based on the findings there were certain participants who were unable to attend all of the session, so they were categorized pass in condition. This is related with other structural schedule as has been discussed earlier.

Based on the evaluation result, it can be seen that learning activities components are all in proper way as the requirements, so this aspect can be categorized under good rating.

\section{c. Monitoring and Evaluation}

Based on monitoring and evaluation, it can be said that these two aspects have been performed. Monitoring is conducted by LPPKK as the consecutive program manager most of the time, customized with the provided presence list.

Limited evaluation has been performing annually in a routine meeting before Ramadhan, as a media to present anything things that have been done and not. The meeting attended by LPPKK and Chancellor parties were going well. But deeper evaluation like spreading questionnaire related to responds has not been enforced by the LPPKK due to lack of human resources. This makes researcher recommends personnel recruitment in LPPKK based on the existed organization structure. On this present time, LPPKK still consists of two members, a director and a staff. The organization itself does not have a secretary which is why it cannot performing its maximum function.

Other than routine meeting, evaluation is also held by the end of program enforcement period. The program has benn documented in the program report presented to Chancellor, accompanied by some important notes for program improvement in the future.

\section{Product Evaluation}

Product evaluation review includes Employers Baitul Arqam participants competency in Al Islam and Muhammadiyah-ism, in theory as well as in practice.

Based on the data it is known that in each coaching period $>90 \%$ participants are passed. Passing grade in this case applies when a participant fulfill 
$>7$ post-test grade, or in good category and attend as minimum as $80 \%$ of materials session. However, several participants were passed in condition, since their absents in material session is less than $80 \%$ presence because they had other responsibilities from the campus. But they were still able to follow post-test. They who have passed in condition will be considered as passed officially if they already attend the postponed sessions in the mext period of Baitul Arqam program or similar Baitul Arqam program held by Muhammadiyah autonomous organization.

As of the implementation in daily life, based on interviews, most of participants said to perform worship practice and theory maximally. Even based on subjective observation, there are several employers who performed their old rite worship 3 months after Ramadhan. A continuous Baitul Arqam is required in order to refresh our religion knowledge. As all level are passed, LPPKK will issue a Baitul Arqam Performance Decree and all of passed participants are allowed to get Employers Baitul Arqam program cerrtificate.

In order to support data validity, reseearcher performed conformability by extending the research duration, as well as performed data triangulation through interviews with telated parties who support Employers Baitul Arqam program. The collected data is supported study result data in general, which has been explained earlier.

\section{CONCLUSION}

Study conclusions can be compiled are as follow:

1. Necessity analysis as well as program purposes and targets in context component is classified as very good. This is also reflects that before designing a program, Muhammadiyah University of Palangkaraya is performing necessity analysis on institution and society needs. On the other hand, BBTHA program purposes and targets fits with Muhammadiyah University of Palangkaraya and LPPKK workforce unit vission, mission, and targets.

2. Planning strategy includes materials, human resources, tools and infrastructure, fund, and learning method of the BBTHA program inputs component is classified as good. The details will be presented as follows: (a) Emloyers Baitul Arqam material is in accordance with the requirements, ie. :Al islam, Muhammadiyah-ism, Fiqih, and Worship Practice can be classified as good. (b) Human resources to support Employers Baitul Arqam program is meet the requirements based on handbook, consist of Muhammadiyah Central Director, Muhammadiyah Regional Director, and Aisyiyah Regional Director of Central Kalimantan, so it can be classified as good. (c) Tools and infrastructure availability is in accordance to the standard and very helpful to support Employers Baitul Arqam program, so it can be classified as good. (d) Funding support from the University already fulfilled Employers Baitul Arqam program needs, so it can be classified as good. (e) Learning method applied in Employers Baitul Arqam program is varied in theory which is followed by practice, so it can be classified as good.

3. Process component performed during Employers Baitul Arqam program is 
classified as good, ie: (a) program schedule enforcement is following the plan, so it can be categorized as good. (b) learning activities performed is in accordance with instructions on the available guidance, therefore it can be categorized as good. (c) monitoring and evaluation have been performed, therefore it can be classified as good.

4. Product component as Employers Baitul Arqam program can be categorized as good. It means that participants competencies in Al Islam and Muhammadiyah-ism is being accomplished in maximum effort.

The final conclusion of context, input, process amd product evaluation process of the Employers Baitul Arqam Program in Muhammadiyah University of Palangkaraya is in good classification. It means that the program can be performed continuously with some improvements.

Based on the above conclusions, researcher determines some recommendations to improve Employers Baitul Arqam program in Muhammadiyah University of Palangkaraya as follows:

1. As of context, a consistency is required to perform the plicy as in accordance with necessities analysis as well as program purposes and targets to improve human resources quality.

2. As of input, improvements are required in:

a. Trainers from the Muhammadiyah Central Director must be given extended coaching duration.

b. With respect to the stakeholder, $2^{\text {nd }}$ Vice Chancellor in this case, it is required to provide learning media tool to support worship practice.

3. As of process, it is required some improvements as follows:

a. With respect to the LPPKK Director, an additional duration for worship practice is required.

b. Monitoring and evaluation should be improved by conducting a routine and periodic monitoring and evaluation.

4. As of product, a thing to recommend is consistency in performing final assessment in case of post test as well as participant discipline while attending all program sessions.

\section{REFERENCES}

Daniel L.Stufflebeam dan Anthony J. Shinkfield. (2007). Evaluation Theory, Models, \& Applications. United States of America: A Wiley Imprint.

Darmadi, Hamid. (2013). Metode Penelitian Pendidikan dan Sosial. Bandung: Alfabeta.

Daryanto. (2012). Evaluasi Pendidikan. Jakarta: PT. Rineka Cipta.

Djaali\&Pudji Muljono. (2008). Pengukuran dalam Bidang Pendidikan. Jakarta: PT. Grasindo.

Emzir. (2008). Metodologi Penelitian Pendidikan. Jakarta: PT. Rajagrafindo Persada.

Furqan, Arief. (2000). Pengantar Penelitian dalam Pendidikan. Surabaya: Usaha Nasional. Hartoyo. (2006). Pengembangan Instrumen Kompetensi Penilik dan Penerapannya di 
Kabupaten Musi Rawas. Jurnal Penelitian dan Evaluasi Pendidikan, Nomor 1, Tahun VIII.

Mardapi, Djemari. (2012). Pengukuran Penilaian \& Evaluasi Pendidikan. Yogyakarta: Nuha Medika

Muhtadi, Ali. (2006). Penanaman Nilai-Nilai Agama dalam Pembentukan Sikap dan Perilaku Siswa Sekolah Dasar Islam Terpadu Luqman Al-Hakim Yogyakarta. Jurnal Penelitian dan Evaluasi Pendidikan, Nomor 1, Tahun VIII.

Muyasaroh, Sutrisno. (2014). Pengembangan Instrumen Evaluasi Cipp Pada Program Pembelajaran Tahfiz Alqur'an Di Pondok Pesantren. Jurnal Penelitian dan Evaluasi Pendidikan, Volume 18, Nomor 2, 215-233.

Purwanto dan Atwi Suparman. (1999). Evaluasi Program Diklat, Jakarta: STIA-LAN Press. 